14. Cherenko, M. S. (2016). The current opinion on management and treatment of hyperthyroidism and other forms of thyrotoxicosis: review of the latest Guidelines of American Thyroid Association (2016). Clinical Endocrinology and Endocrine Surgery, 4 (56), 87-94. doi: http://doi.org/10.24026/1818-1384.4(56).2016.87324

Received date 26.05.2020 Accepted date 19.06.2020

Published date 31.07.2020

Vira Tseluyko, MD, Professor, Head of Department, Renowned Leader of Science and Technics of Ukraine, Department of Cardiology and Functional Diagnostics, Kharkiv Medical Academy of Postgraduate Education, Amosova str., 53, Kharkiv, Ukraine, 61176

E-mail: viratseluyko@ukr.net

Daria Korchagina, Postgraduate Student, Department of Cardiology and Functional Diagnostics, Kharkiv Medical Academy of Postgraduate Education, Amosova str., 53, Kharkiv, Ukraine, 61176

E-mail: korchagina.daria@ukr.net

UDC 547.962.9: 61-08

DOI: $10.15587 / 2519-4798.2020 .209167$

\title{
KERATITIS CAUSED BY PSEUDOMONAS AERUGINOSA: TREATMENT IN THE EXPERIMENT
}

\section{N. Malachkova, N. Kryvetska, V. Kryvetskyi}

Метою дослідження було дослідити ефективність лікування викликаного Р. aеruginosa кератиту в експерименті з використанням офіцинальних офтальмологічних форм антибіотиків, ефективних проти збудника.

Матеріали та методи. Гнійний кератит викликали у 36 дорослих кроликів масою 3-3,5 кг иляхом нанесення клінічного штаму P. aеruginosa у вигляді суспензї одноденної культури мікроорганізму в концентрації $5 \times 108$ КУО/мл на частково деепітелізовану (на площуі приблизно 1 см²) рогівку з подальшим покриттям протягом 24 годин м'якою контактною лінзою з белафілкону $A$ (вміст води: $36 \%$, киснепроникність DK/t:110.0). У половині випадків мікробні біоплівки попередньо вирощували на поверхнях контактних лінз шляхом інкубації в бульйонній культурі штаму P. aeruginosa.

Лікування кератиту проводили за допомогою очних офіцинальних форм антибіотиків: левофлоксацину 0,5\%, ичипрофлоксацину 0,3\%, тобраміцину 0,3\%. Їх ефективність проти штаму Р. aеruginosa попередньо була доведена іп vitro. Тварин поділяли на три співставні за ступенем тяжкості групи кератитів, у кожній з яких лікування проводили одним із трьох зазначених антибіотиків. У половині випадків у межах кожної групи антибіотик поєднувався з офіцинальною очною формою декаметоксину 0,02\%. Антибіотики застосовували в режимі якнайчастішої інстиляиї перші 2 дні після початку гнійного кератиту, потім 5 i 4 рази на день.

Очінка процесу проводилась на онові клінічних ознак, культивування, офтальмологічного дослідження рогівки з використанням флюоресцеїнового тесту та фотофіксацією. Тварин виводили на 7, 10, 14 добу (залежно від строків епітелізації ураженої рогівки).

Результати. Всього було змодельовано 36 випадків гнійного кератиту, спричиненого Р. aeruginosa y кролів: 8 помірного (22,2 \%), 13 середньо-важкого (36,6\%), 15 - важкого (41,7\%).

Незалежно від обраного антибіотика, через 10-12 годин після видалення зараженої контактної лінзи та початку лікування зазвичай спостерігалося інтенсивне посилення запального процесу. Згодом запальні явища поступово згасали до повної епітеліалізащї рогівки, щзо відбувалась на 7-8 добу при помірному кератиті, 10-12 добу для важких та середньо-важких у I та III групі, та 12-14 добу (для важких та середньо-важких у II групі). Порівняно з I групою (0,5 \% левофлоксачин), зменшення запалення рогівки та епітелізація ураження у групі II (ципрофлоксацин 0,3%) затримувались на 1-2 дні. Застосування 0,3\% тобрамічину (III група) забезпечило найвищий контроль гнійного запалення протягом перших трьохчотирьох днів, однак далі спостерігалось уповільнення позитивної динаміки та затримка епітеліізаціі порівняно з групою I. Для всіх досліджуваних груп застосування комбінованої антибактеріальної терапії 3 декаметоксином супроводжувалося прискоренням регресї̈ гнійно-запальних уражень, особливо через зменшення кон'юнктивальної реакиї та гноєвиділення.

Як наслідок лікування, у більшості (69,5\%) випадків спостерігалось виникнення ділянок непрозорого помутніння рогівки різної величини. Більмо сформувалося більш ніж у третині випадків, у всіх - внаслідок 
важкого кератиту. Разом з тим, у всіх тварин вдалося уникнути ускладнень, які могли призвести до втрати ока (абсцес рогівки, перфорація, кератомаляція).

Бактеріологічні посіви з поверхні ока показали зменшення присутності P. aeruginosa через 48 годин із $100 \%$ до 63,9\% випадків та повне зникнення збудника через 3 дні. Однак у 11 з 15 важких кератитів (30,6\% від числа загальних спостережень) мікробіологічні дослідження рогівки, отримані після виведення тварин, були позитивними щзоо Р. аетияіпоsа навіть після повної епітелізації ураження.

Висновки. Лікування експериментального кератиту, спричиненого P. aеruginosa, антибіотиками, чутливість збудника до яких доведена, в режимі найбільш ранніх і найчастіших інстиляцій протягом перших 48 годин у поєднанні з видаленням гнійних мас забезпечило зменшення запалення, відновлення поверхні рогівки та запобігло найсерйознішим ускладненням, наприклад, кератомаляції та перфорації рогівки.

Раннє та активне протимікробне лікування ефективними препаратами призвело до елімінації Р. aеrugenоsа з поверхні ока в перші 2-3 дні. Однак у 30,6 \% випадків не було досягнуто повної ерадикації збудника $з$ рогівки.

Вибір антибіотика з переліку препаратів з доведеною чутливістю до них Р. aеrugenоsа не мав істотного впливу на результат лікування. Одночасне застосування декаметоксину підсилює ефект і дещзо покрашує результати

Ключові слова: експериментальний кератит, Pseudomonas aeruginosa, лікування, левофлоксацин, ичипрофлоксацин, тобраміцин, декаметоксин

Copyright (C) 2020, N. Malachkova, N. Kryvetska, V. Kryvetskyi.

This is an open access article under the CC BY license (http://creativecommons.org/licenses/by/4.0).

\section{Introduction}

Nowadays, keratitis is a serious problem of ophthalmology due to wide spreading, tendency to chronization, difficulties in treatment and often severe consequences, such as corneal perforation, endophthalmitis, complicated cataracts, secondary glaucoma, etc. [1, 2]. Complicated or undertreated microbial keratitis is a leader among the causes of blindness [3, 4].

Bacteria dominate among the causes of infectious keratitis [1,5]. Among them, Pseudomonas aeruginosa occupies a special place in terms of resistance to treatment and severity of complications [6]. The microorganism is included to the WHO Global List of Pathogens of Priority Antibiotic-Resistant Bacteria, to identify priority of research and development of novel and effective methods of antibiotic treatment (WHO, Geneva 25-27 January 2017) [7].

In recent years, the pathogen has shown an increase in the frequency of seeding at purulent keratitis in both monoculture and associations up to 39.0-44.6\% and $20.0 \%$, respectively $[5,6]$.

Serious risk factors for keratitis are: contact lens wearing, traumatic corneal injuries, ocular surface changes (blepharitis, dry eye, etc.), systemic diseases (diabetes, rheumatoid arthritis, alcoholism, AIDS), systemic and local steroid treatment. Elderly people, patients of intensive care centers, hospices, and social institutions are in the risk zone of pseudomonad infection [8-10].

The standard of treatment of pseudomonad keratitis includes topical use of fluoroquinolones, cephalosporins, aminoglycosides under conditions of their frequent instillation, especially in the first day, creating a sufficient concentration of the drug at the site of lesion [11].

At the same time, the search for effective methods of treatment of severe and threatening to vision keratitis with a central location and a size of more than $3 \mathrm{~mm}$, ulceration and signs of anterior chamber reaction remains an urgent task $[1,2,12]$. The possibility of P.aeruginosa eradication and conditions for its achievement at purulent keratitis require further investigation [13]. The point seems important given the natural ability of P.aeruginosa to form biofilm forms, to adhere closely to surfaces made of synthetic polymeric materials, in particular, contact lenses $[14,15]$, to migrate deep into the corneal tissues due to virulence factors (primarily proteases) [16-18]. The search for ways to increase the effectiveness of antibiotic therapy and overcome antibiotic resistance also remains relevant.

The aim of the study was to investigate the effectiveness of treatment of keratitis caused by Pseudomonas aeruginosa in an experiment using official ophthalmic forms of antibiotics, which are effective against the pathogen.

\section{Materials and methods}

The experimental study was performed at the Scientific and Biological Clinic of National Pirogov Memorial Medical University, Vinnytsya during 2019-2020, in compliance with the ethical norms provided by Directive 2010/63/EU of the European Parliament and of the Council of 22 September 2010 on the protection of animals used for scientific purposes and the norms of biomedical ethics approved by the First National Congress of Bioethics of Ukraine), as well as the Law of Ukraine No. 3447-IV "On protection of animals from cruel treatment" (Kyiv, 2006). The Bioethics Commission of the National Pirogov Memorial Medical University, Vinnytsya (Ukraine) confirmed the compliance of study with ethical rules on October 27, 2016 (Protocol No 10).

Adult 36 rabbits weighing 3-3.5 kg were kept in separate cages in standard conditions (natural feeding and water supply, light/dark cycle for every 12 hours). 
Keratitis in animals was caused by applying a clinical strain of $P$. aeruginosa as a suspension of oneday culture of the microorganism at a concentration of $5 \times 10^{8} \mathrm{CFU} / \mathrm{ml}$, which corresponds to the $0.5 \mathrm{McF}$ arland standard, on the partially de-epithelialized (approximately $1 \mathrm{~cm}^{2}$ ) cornea followed by coating for 24 hours with soft contact lens made of belafilcon A (water content: $36 \%$, oxygen permeability DK/t:110.0). In half of the cases, microbial biofilms were pre-grown on the contact lens surfaces via incubation into the broth culture of $P$. aeruginosa strain (concentration of cells $10^{6}-10^{7}$ per $1 \mathrm{ml}$ ) at a temperature of $37^{\circ} \mathrm{C}$ for 48 hours [19-21]. Keratitis was modeled on one of the eyes of each animal.

For the treatment of keratitis ocular official forms of antibiotics: levofloxacin $0.5 \%(5 \mathrm{mg} / \mathrm{ml})$, ciprofloxacin $0.3 \%(3 \mathrm{mg} / \mathrm{ml})$, tobramycin $0.3 \%(3 \mathrm{mg} / \mathrm{ml})$ were used. Their effectiveness against the strain of $P$. aeruginosa was previously proven in vitro by standard serial dilutions of the drug in a liquid nutrient medium (meat-peptone broth) to determine the minimum inhibitory concentration of antimicrobial substance, followed by seeding on a dense nutrient medium (meat-peptone agar) to determine the minimum bactericidal concentration [22].

Animals were divided randomly into 3 groups of 12 individuals; treatment in each was carried out by one of the mentioned drugs. In half of the cases within each group, the antibiotic was combined with the ocular official form of decamethoxine $0.02 \%(0.2 \mathrm{mg} / \mathrm{ml})$.

The antibiotics were used in the mode of the most frequent instillation (as on study conditions) for the first 2 days after the onset of purulent keratitis. For that purpose, the drug was instilled every fifteen minutes for the first 4 hours, then every 2 hours for another 12 hours, followed by an eight-hour night pause. On the second day, antibiotics were used every 2 hours for 16 hours. After 48 hours, until the negative as for $P$. aeruginosa results of bacterial culture were obtained, instillations were performed 5 times a day, and then until the animals were removed from the experiment 4 times a day. In that cases, where combine therapy was used, decamethoxine was instilled 5 minutes before the antibiotic in a volume of $0.2-0.3 \mathrm{ml}$; it also provided a wash to remove purulent masses.
The assessment of the process included evaluation of clinical signs of keratitis, bacteriology, ophthalmological examination of the cornea with fluorescein test and photofixation. Material for microbiological examination was collected with a sterile swab from the time of removal of contact lenses and every 24 hours until two consecutive negative results.

Animals were removed from the study on days $7^{\text {th }}, 10^{\text {th }}, 14^{\text {th }}$ (depending on the term of epithelialization of the affected cornea) in aseptic conditions by introducing of air $\left(1-1.5 \mathrm{~cm}^{3}\right)$ into the marginal vein of the ear. Every time, the cornea, which was collected under aseptic conditions, was divided into two segments: one was placed into sterile meat-peptone broth to incubate for $24-48$ hours, followed by sowing the contents of the medium on dense nutrient agar to detect P.aeruginosa colonies; another segment was deepen into $40 \%$ formaldehyde solution for further histological examination.

Statistical processing included the calculation of descriptive characteristics with STATISTICA 6.0 program using a comparative assessment of distributions for a number of accounting signs.

\section{Results}

Totally, 36 cases of purulent keratitis caused by $P$. aeruginosa in rabbits were modelled: 8 moderate (22.2\%), 13 semi-severe (36.6\%), 15 - severe (41.7\%). The animals were divided into three groups, in each of which treatment was performed with one of the three above antibiotics: levofloxacin $0.5 \%$, ciprofloxacin $0.3 \%$, tobramycin $0.3 \%$ (Table 1 ). The groups were corresponding as for severity of keratitis.

Regardless of the chosen antibiotic, the clinical course of experimental keratitis in rabbits of all groups was characterized by a certain similarity. Thus, 10 12 hours after removal of the infected contact lens and the start of treatment, there was mostly a burst enhancement of the inflammatory process in the cornea in the form of spreading the area of edema and corneal opacity and increasing of its intensity. The fluorescence test revealed a deep diffuse staining without clear contours, in size that significantly exceeded the area of the initial lesion (Fig. 1).

Distribution of experimental animals by study groups depending on the used antibiotic

Table 1

\begin{tabular}{|c|c|c|c|c|c|c|}
\hline \multirow{2}{*}{$\begin{array}{c}\text { The severity of experimental } \\
\text { keratitis }\end{array}$} & \multicolumn{2}{|c|}{ Group I $(\mathrm{N}=12)$} & \multicolumn{2}{c|}{ Group II $(\mathrm{N}=12)$} & \multicolumn{2}{c|}{ Group III (N=12) } \\
\cline { 2 - 7 } & $\mathrm{L}(\mathrm{N}=6)$ & $\mathrm{L}+\mathrm{D}(\mathrm{N}=6)$ & $\mathrm{C}(\mathrm{N}=6)$ & $\mathrm{C}+\mathrm{D}(\mathrm{N}=6)$ & $\mathrm{T}(\mathrm{N}=6)$ & $\mathrm{T}+\mathrm{D}(\mathrm{N}=6)$ \\
\hline Moderate* $(\mathrm{N}=8)$ & $1(1 \#)$ & $1(1 \#)$ & $2(1 \#)$ & 2 & 1 & $1(1 \#)$ \\
\hline Semi-severe** $(\mathrm{N}=13)$ & 2 & 2 & 2 & 2 & 3 & 2 \\
\hline Severe*** $(\mathrm{N}=15)$ & 3 & 3 & 2 & 2 & 2 & 3 \\
\hline
\end{tabular}

Note: L-levofloxacin $0.5 \%$; C-ciprofloxacin $0.3 \%$; T-tobramycin $0.3 \%$; D-decamethoxine $0.02 \% ; *$ - swelling and opacity of the cornea, through which the deeper structures of the eye were seen; an area of opacity did not exceed the area of de-epithelialization; moderate muco-purulent discharge, conjunctival hyperemia were present; ** - swelling and opacity of the cornea, through which the deeper structures of the eye were partially seen; an area of opacity exceed the area of de-epithelialization, but did not up to subtotal or total; moderate discharge of viscous whitish pus, severe conjunctival hyperemia, chemosis were present; *** - swelling and subtotal or total opacity; deeper structures of the eye are not visible even on the periphery; significant purulent discharge, severe conjunctival hyperemia, chemosis were present; \#-cases where enhancement on the first day did not occurred 
Such enhancement took place in 32 of 36 observations $(88.9 \%$ ), with the small exception of 4 cases. Subsequently, at moderate keratitis in all groups, the inflammatory process showed a gradual attenuation with complete corneal epithelialization for $7-8$ days.

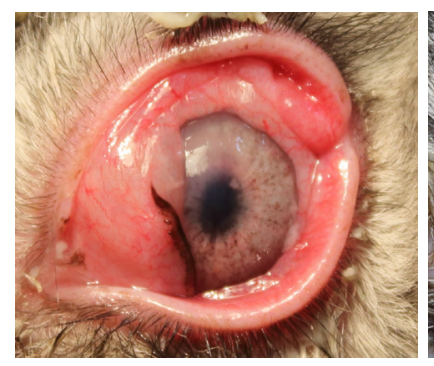

$a$

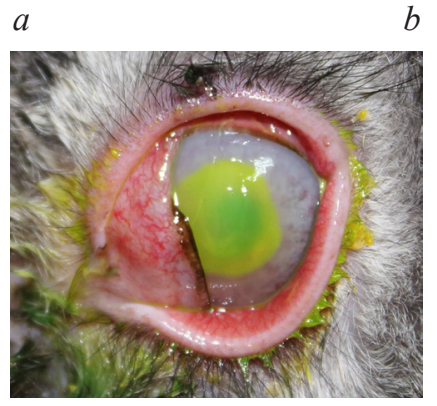

c

Fig. 1. Enhancement of the inflammatory process in the cornea (case of tobramycin group): $a$ - just after contact lens removal; $b$ - in 10 hours; $c$ - under fluorescein test

Cases of severe and semi-severe keratitis were characterized by a complex sequence of changes in clinical manifestations.

Within animals of Group I the intense purulent discharge, which required removing by washing, was present for 3-4 days. Conjunctival chemosis increased until the end of the second day, then gradually decreased and disappeared by $4^{\text {th }}-5^{\text {th }}$ days. The hyperemia remained intense for 5-6 days. Corneal swelling and opacity was maximal on the second-third day. Deformation of the corneal sphericity in the form of a paracentral conical protrusion occurred within four eyes; at the same time corneal surface was covered with a gelatinous layer which could not be removed with a tampon. In two severe cases, on the third or fourth day, signs of initial ulceration appeared; it lasted about 24-48 hours. Stabilization happened mostly on $5^{\text {th }}-6^{\text {th }}$ day. After that there was a regress of inflammatory manifestations and improvement of the cornea: its sphericity came to restore; the edema reduced; turbidity decreased in size that was accompanied with appearance and expand from the periphery a rim of transparent cornea. Epithelialization of corneal lesion began on day $7^{\text {th }}-8^{\text {th }}$ (the staining area at fluorescein instillation decreased, its edges were delineated clearly) and ended on day $10^{\text {th }}-12^{\text {th }}$, which was confirmed by a negative fluorescein test (Fig. 2).

Among Group II, the proportion of severe keratitis was the lowest (4 out of 12 vs. 6 out of 12 in Group I and 5 out of 12 in Group III, see table 1). The severity of conjunctival inflammation was comparable to that in
Group I: purulent discharge lasted up to third-fourth day; chemosis lasted until fourth-fifth day, and intense redness - up to seventh-eighth day. The presence of thick pus required frequent rinsing with sterile saline. From the cornea, the retention of signs of inflammation at the maximum level lasted up to 4-5 days. At the same time, along with intense edema, diffuse widespread opacity of the cornea, there was a violation of its sphericity, fixed fibrin layers appeared on the surface. Between fourthfifth day, and seventh-eighth day, gradual positive changes in the cornea, which showed the beginning of the regression of purulent inflammation, came. It was regarded as a period of stabilization. The area of turbidity gradually became separated, edema decreased; the sphericity of the cornea was restoring. Subsequently, the dynamics of improvement accelerated significantly. Epithelialization started on day $9^{\text {th }}-10^{\text {th }}$ and completed on day $12^{\text {th }}$ $14^{\text {th }}$. Thus, in comparison with the Group I, the reducing of the corneal inflammation and lesion epithelialization within the Group II was 1-2 days delayed.

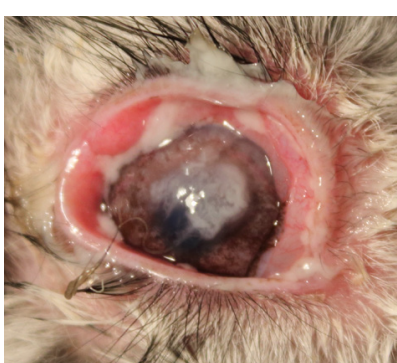

$a$

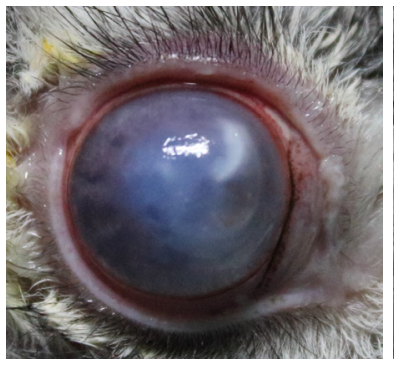

$c$

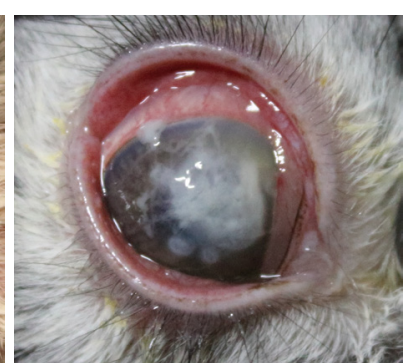

$b$

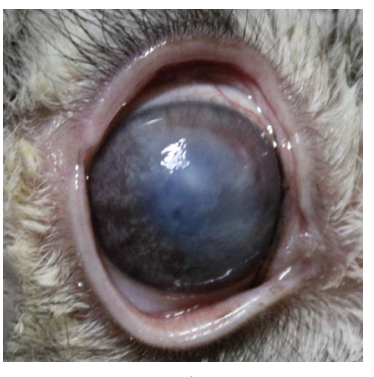

$d$
Fig. 2. Changes in clinical manifestations of the inflammatory process in the cornea (case of levofloxacin group): $a$ - just after contact lens removal; $b$ - in 10 hours; $c$ - on the $5^{\text {th }}$ day; $d$ - on the $12^{\text {th }}$ day

Within animals of Group III, purulent discharge was observed for up to 4-5 days, which also required repeated washing. Chemosis lasted for an average of 3 days, intense redness was observed up to $6^{\text {th }}-7^{\text {th }}$ day. Persistence of the most pronounced signs of corneal damage (severe edema, widespread intense turbidity, violation of spherical shape, deep diffuse fluorescein staining without clear contours, and ulceration in two cases) was the least long (mostly lasted until the third day). Within third-fourth day there was stabilization with subsequent somewhat slowed regression of corneal manifestations. The beginning of epithelialization took place on $7^{7^{\text {th }}-9^{\text {th }}}$ day and its completion on $10^{\text {th }}-12^{\text {th }}$ day. Thus, the use of $0.3 \%$ tobramycin provided the highest 
control of purulent inflammation during the first three to four days, but further there was a slowdown in the positive dynamics and delayed epithelialization compared with Group I.

For all study groups, the use of combination antibiotic therapy with decamethoxine was accompanied by acceleration in regression of purulent-inflammatory lesions, especially due to a decrease in conjunctival response and pyorrhea. As for the cornea, the reduction of the area of turbidity and its edema shown some acceleration (mostly for 1-2 days), but it did not lead to the earlier epithelialization. The results of treatment of experimental keratitis within study groups are presented in Table 2.

As can be seen from the above data, in most cases $(69.5 \%)$ there were areas of opaque turbidity of various sizes among the outcomes. Total leucoma was noted in more than a third of cases; all of them have formed due to severe keratitis. It is important to note that in all animals it was managed to avoid the complications that could lead to eye loss (corneal abscess, perforation, malacia). It should also be reported that in animals of Groups II and III, the combined use of antibiotics with decamethoxine reduced the number of total leucoma among the outcomes compared with consequences after monotherapy (4 vs 6 cases, Table 2). The results of bacteriological examination of the presence of $P$. aeruginosa on the surface and in the depth of the cornea are presented in Table 3 .

These data show a relatively early (after $48 \mathrm{~h}$ ) decrease from $100 \%$ to $63.9 \%$ in the culturing of the pathogen from the surface of the eye and its complete disappearance after 3 days in all cases of treatment with antibiotics of proven effectiveness against $P$. aeruginosa. However, in 11 of 15 severe keratitis (30.6\% of total observations) microbiological tests of the cornea, obtained after removal of animals, were positive as for $P$. aeruginosa even after lesion complete epithelialization.

\section{Discussion}

The proposed experimental model provides a stable replication of purulent keratitis of varying severity in animals, with a predominance of severe, which creates appropriate conditions for their comprehensive investigation.

Within management of keratitis, caused by P. aeruginosa, an important issue is the choice of antibiotic, its concentration and regimen. The first aspect is considered relatively determined (usually levofloxacin, tobramycin, ceftazidime, gentamicin, cefuroxime, ciprofloxacin are offered) $[1,12,23]$.

Results of treatment of experimental keratitis by study groups depending on the used antibiotic

Table 2 (monotherapy and combination with decamethoxine)

\begin{tabular}{|c|c|c|c|c|c|c|c|}
\hline \multirow{2}{*}{$\begin{array}{c}\text { Outcomes } \\
\text { (condition of the cornea) }\end{array}$} & \multicolumn{2}{|c|}{ Group I (N=12) } & \multicolumn{2}{|c|}{ Group II (N=12) } & \multicolumn{2}{|c|}{ Group III (N=12) } & Total \\
\cline { 2 - 8 } & $\mathrm{L}(\mathrm{N}=6)$ & $\mathrm{L}+\mathrm{D}(\mathrm{N}=6)$ & $\mathrm{C}(\mathrm{N}=6)$ & $\mathrm{C}+\mathrm{D}(\mathrm{N}=6)$ & $\mathrm{T}(\mathrm{N}=6)$ & $\mathrm{T}+\mathrm{D}(\mathrm{N}=6)$ & $36(100 \%)$ \\
\hline Nebula $^{\circ}$ & - & 1 & 1 & - & - & 1 & $3(8.3 \%)$ \\
\hline Macula $^{\circ \circ}$ & 2 & 1 & 1 & 2 & 1 & 1 & $8(22.2 \%)$ \\
\hline Not total leucoma $^{\circ \circ \circ}$ & 2 & $2(1 *)$ & 1 & 2 & 2 & $2(1 *)$ & $11(30.6 \%)$ \\
\hline Total leucoma & & 2 & 3 & 2 & $3\left(1^{\circ}\right)$ & 2 & $14(38.9 \%)$ \\
\hline
\end{tabular}

Note: L-levofloxacin $0.5 \%$; C-ciprofloxacin $0.3 \%$; T-tobramycin $0.3 \%$; D-decamethoxine $0.02 \% ;^{\circ}$ - superficial translucent greyish turbidity with blurred borders, invisible to the naked eye; ${ }^{\circ}$ - saturated translucent demarcated whitish turbidity visible to the naked eye; ${ }^{\circ \circ}$ - central, peripheral, eccentric (possibly inhomogeneous) area of dense opaque whitish tissue surrounded by a transparent cornea; ${ }^{\circ 00}$ - widespread dense opaque thickened homogeneous white scarred area; * ulcer healing

Table 3

Presence of $P$. aeruginosa in cultures at different periods of treatment of experimental keratitis

\begin{tabular}{|c|c|c|c|c|c|c|c|}
\hline \multirow{2}{*}{$\begin{array}{c}\text { Time from the beginning of } \\
\text { treatment, hours }\end{array}$} & \multicolumn{7}{|c|}{ P. aeruginosa in cultures (N of animals) } \\
\cline { 2 - 9 } & \multicolumn{2}{|c|}{ Group I (N=12) } & \multicolumn{2}{|c|}{ Group II (N=12) } & \multicolumn{2}{|c|}{ Group III (N=12) } & Total \\
\cline { 2 - 9 } & $\mathrm{L}(\mathrm{N}=6)$ & $\mathrm{L}+\mathrm{D}(\mathrm{N}=6)$ & $\mathrm{C}(\mathrm{N}=6)$ & $\mathrm{C}+\mathrm{D}(\mathrm{N}=6)$ & $\mathrm{T}(\mathrm{N}=6)$ & $\mathrm{T}+\mathrm{D}(\mathrm{N}=6)$ & 36 \\
\hline 0 & 6 & 6 & 6 & 6 & 6 & 6 & $36(100 \%)$ \\
\hline 24 & 6 & 6 & 6 & 6 & 6 & 6 & $36(100 \%)$ \\
\hline 48 & 1 & 4 & 6 & 3 & 3 & 6 & $23(63.9 \%)$ \\
\hline 72 & 0 & 0 & 0 & 0 & 0 & 0 & 0 \\
\hline 96 & 0 & 0 & 0 & 0 & 0 & 0 & 0 \\
\hline Cornea (after removal) & 3 & 3 & 1 & 1 & 2 & 1 & $11(30.6 \%)$ \\
\hline
\end{tabular}


For topical use, drugs are recommended in sufficient, but not damaging the corneal epithelium concentration.

The official forms of antibiotics were chosen taking into account a previously conducted in vitro exploration of the effectiveness of antibiotics against 11 strains of $P$. aeruginosa (reference ATCC 27853 and ten clinical, including that used as a pathogen in reported study). According to its results, it was shown that the ophthalmic dosage forms, used in the experiment, contain antibiotics in concentrations, which are significantly exceeding bactericidal even to resistant strains: for levofloxacin 116-31000 times, for ciprofloxacin 9875000 times and for tobramycin 200-120000 times [22]. Under such conditions, overcoming in vivo the resistance mechanisms (biofilm formation, deep intrastromal penetration), which lead to the pathogen inaccessible even for potentially effective antibiotics, becomes more important that the lifting of substances concentrations up. This position is confirmed by the results of bacteriological tests, which reveal the absence of the pathogen on the surface after 48-72 hours therapy, however, in 11 of 36 cases (30.6\%) postmortem corneal cultures were positive even after epithelialization.

Obviously, the combination of antibiotics with drugs even without direct bactericidal activity as for the pathogen, but which improve the accessibility of antimicrobial substance, significantly increasing its effectiveness at normal concentrations is promising [13, 18, 24]. In this respect, decamethoxine, which combines detergent action with low keratotoxic effect [25] and provides in vitro reduction of bactericidal concentrations of levofloxacin, ciprofloxacin, tobramycin by $1.7-4$ times in combination [22], is advantageous. An additional positive is the mechanical removal by washing of purulent-fibrinous masses with a solution of decamethoxine before instillation of the antibiotic at combined usage.

Regarding subconjunctival antibiotics, the positions differ from support [12] to denial [11] due to the risk of additional injury at the injection site as well as the relatively short-term effect. Then, the loading treatment with antibiotic instillations every 5 minutes for half an hour creates a dose of saturation in the cornea, comparable to that achieved by injection under the conjunctiva [1]. After all, the choice of medication and treatment regimen often comes down to finding a compromise between the temptation to act as aggressively as possible on the pathogen and to avoid long-term use of drugs with severe keratotoxicity in high concentrations. At presented study, the optimal level of that balance was demonstrated by $0.5 \%$ levofloxacin. The drug invariably had a therapeutic effect on the purulent process and supplied a stable improvement. Low keratotoxicity of levofloxacin is confirmed by Padma Bezwada et al. [26]. For comparison, $0.3 \%$ tobramycin initially showed a strong antipseudomonad potential, especially during the first three to four days, but then there was a slowdown in positive dynamics and delayed epi- thelialization, which can be regarded to manifestation of epithelial toxicity of aminoglycosides [1].

Interesting conclusions were done after conducting clinical and microbiological parallels in the dynamics of the process. The progression of experimental keratitis manifestations at the end of the first day was indicative in most cases, even against the background of the initiated intensive antibiotic therapy. It is consistent with the idea of the specificity in pathogenesis of pseudomonad lesions, in which the active action of cellular and extracellular virulence factors under the conditions of loss of the external barrier due to epithelial defects triggers a cascade of damaging mechanisms, primarily - the destruction of collagen stroma of the cornea, which causes critical deepen and spreading of pathogen into the tissue. It is important, that some aggressive factors (e.g. proteases, endotoxins, etc.) continue to act even after the death of the pathogen [16]. And only a critical decrease in microbial load (in our study occurred by the end of the second day of antibiotic therapy) marks the stabilization of the inflammatory process and the beginning of positive dynamics. In general, positive bacteriological changes (disappearance of the causative agent in cultures from the surface of the eye in a third of cases after 48 hours and in the rest after 72 hours) are significantly ahead of the dynamics of clinical indicators.

It is also necessary to compare the morphological consequences of experimental keratitis (completion of corneal epithelization, stroma restoring) with the level of eradication of the pathogen. In this regard, a proportion (30.6\%) of positive as for P. aeruginosa presence microbiological tests of the cornea, obtained post mortem, is rather high. Because of this, it should once again be emphasized the natural ability of the pathogen to resist both natural defense systems and pharmacological factors, using various mechanisms, which complicates its complete elimination, even through the early use of antibiotics with proven effectiveness.

Study limitations. The cases of moderate, semisevere and severe purulent keratitis caused by $P$. aerugino$s a$ in rabbits were used as the experimental model for the achievement of study purpose. The examples of mild keratitis were excluded as it disappears spontaneously in rabbits with complete corneal epithelisation within 5-6 days due to the action of local natural defence mechanisms, even without antimicrobial therapy.

Prospects for further research. The reported study demonstrates results of treatment of experimental keratitis caused by $P$. aeruginosa in rabbits with the antibiotics, to which the sensitivity of pathogen is confirmed, in the mode of intensively performed monotherapy and in antibiotic-decamethoxine combination. The next steps are to investigate the effectiveness of simultaneous use of more than one antibiotic as well as their combinations with drugs without direct bactericidal activity. In addition, the proposed experimental model is promising for studying of various aspects of bacterial corneal lesions associated with contact lenses wearing. 


\section{Conclusions}

Treatment of experimental keratitis caused by $P$. aeruginosa, with antibiotics, to which the sensitivity of pathogen is proven, in the mode of the earliest and most frequent instillations on the first 48 hours in combination with removal of purulent masses provided reducing of inflammation, restoring of cornea surface and prevents the most serious complications, e. g. corneal perforations and keratomalacia. Early and active antimicrobial treatment with effective drugs led to the elimination of $P$. aerugenosa from the ocular surface in the first
2-3 days. However, in $30.6 \%$ of cases there was no complete eradication of the pathogen from the cornea.

The choice of antibiotic from those, to which the sensitivity of $P$. aerugenosa is proven, did not have a significant influence on treatment outcome. Concomitant use of decamethoxine makes better effect and somewhat improves the results.

\section{Conflict of interests}

The authors declare that they have no conflicts of interest.

\section{References}

1. Güell, J. L. (Ed.) (2015). Cornea. Vol. 6. ESASO Course Series. Basel: Karger, 127. doi: http://doi.org/10.1159/000381489

2. Raphalyuk, S. Y. (2015). The possibility of metabolic correction of pathological disorders in induced keratitis in animals with dry eye syndrome. Ophthalmology, 2 (2), 211-120.

3. Zamani, M., Panahi-Bazaz, M., Assadi, M. (2015). Corneal collagen cross-linking for treatment of non-healing corneal ulcers. Journal of Ophthalmic and Vision Research, 10 (1), 16-20. doi: http://doi.org/10.4103/2008-322x.156087

4. Gokhale, N. (2008). Medical management approach to infectious keratitis. Indian Journal of Ophthalmology, 56 (3), 215 220. doi: http://doi.org/10.4103/0301-4738.40360

5. Farias, R., Pinho, L., Santos, R. (2017). Epidemiological profile of infectious keratitis. Revista Brasileira de Oftalmologia, 76 (3), 116-120. doi: http://doi.org/10.5935/0034-7280.20170024

6. Wang, M., Smith, W. A., Duncan, J. K., Miller, J. M. (2017). Treatment of Pseudomonas Keratitis by Continuous Infusion of Topical Antibiotics With the Morgan Lens. Cornea, 36 (5), 617-620. doi: http://doi.org/10.1097/ico.0000000000001128

7. Tacconelli, E., Carrara, E., Savoldi, A., Kattula, D., Burkert, F. (2017). Global priority list of antibiotic-resistant bacteriatoguideresearch, discovery, and development of new antibiotics World Health Organization. Available at: https://www.who.int/medicines/ publications/WHO-PPL-Short_Summary_25Feb-ET_NM_WHO.pdf

8. Green, M., Apel, A., Stapleton, F. (2008). Risk Factors and Causative Organisms in Microbial Keratitis. Cornea, 27 (1), 22-27. doi: http://doi.org/10.1097/ico.0b013e318156caf2

9. Jin, H., Parker, W. T., Law, N. W., Clarke, C. L., Gisseman, J. D., Pflugfelder, S. C. et. al. (2017). Evolving risk factors and antibiotic sensitivity patterns for microbial keratitis at a large county hospital. British Journal of Ophthalmology, 101 (11), $1483-1487$. doi: http://doi.org/10.1136/bjophthalmol-2016-310026

10. Zimmerman, A. B., Nixon, A. D., Rueff, E. M. (2016). Contact lens associated microbial keratitis: practical considerations for the optometrist. Clinical Optometry, 8, 1-12. doi: http://doi.org/10.2147/opto.s66424

11. Dart, J. K. G., Seal, D. V. (1988). Pathogenesis and therapy of pseudomonas aeruginosa keratitis. Eye, 2 (S1), S46-S55. doi: http://doi.org/10.1038/eye.1988.133

12. Rykov, S. A., Lemziakov, G. G., Bakbardina, L. M., Bakbardina, I. I. (2009). Zabolievaniya rogovitsy. Kyiv, 244.

13. Lambert, R. J. W., Hanlon, G. W., Denyer, S. P. (2004). The synergistic effect of EDTA/antimicrobial combinations on Pseudomonas aeruginosa. Journal of Applied Microbiology, 96 (2), 244-253. doi: http://doi.org/10.1046/j.1365-2672. 2004.02135.x

14. Melezhyk, I. A., Yavorskaya, N. V., Shepelevich, V. V., Kokozay, V. N. (2013). The role of biofilms in pseudomonas aeruginosa endogenous infections. Biulleten Orenburgskogo nauchnogo centra UrO RAN, 3.Available at: http://elmag.uran.ru:9673/magazine/Numbers/2013-3/Articles/5Melezhik(2013-3).pdf

15. Mulcahy, L. R., Isabella, V. M., Lewis, K. (2013). Pseudomonas aeruginosa Biofilms in Disease. Microbial Ecology, 68 (1), 1-12. doi: http://doi.org/10.1007/s00248-013-0297-x

16. O’Callaghan, R., Caballero, A., Tang, A., Bierdeman, M. (2019). Pseudomonas aeruginosa Keratitis: Protease IV and PASP as Corneal Virulence Mediators. Microorganisms, 7 (9), 281. doi: http://doi.org/10.3390/microorganisms7090281

17. Marquart, M. E. (2011). Animal Models of Bacterial Keratitis. Journal of Biomedicine and Biotechnology, 2011, 1-12. doi: http://doi.org/10.1155/2011/680642

18. McClellan, S., Jiang, X., Barrett, R., Hazlett, L. D. (2015). High-Mobility Group Box 1: A Novel Target for Treatment of Pseudomonas aeruginosa Keratitis. The Journal of Immunology, 194 (4), 1776-1787. doi: http://doi.org/10.4049/jimmunol.1401684

19. Malachkova, N. V., Kryvetska, N. V., Vovk, I. M., Kryvetskyi, V. F. (2020). Pat. No. 141155. Method of modeling of pseudomonad keratitis in rabbits. MPK: C12Q 1/00, C12R 1/385. G09B 23/28. No. u201908915. declared: 23.07.19; published: 25.03.2020, No. 6 .

20. Malachkova, N. V., Kryvetska, N. V., Vovk, I. M., Kryvetskyi, V. F. (2020). Pat. No. 141156. Method of modeling of associated with contact lens pseudomonad keratitis in rabbits. MPK: C12Q 1/00, G09B 23/28, C12R 1/385. declared: 23.07.19; published: 25.03.2020, No. 6 . 
21. Malachkova, N. V., Kryvetska, N. V., Vovk, I. M., Kovalenlo, I. M., Kryzhanovskaya, A. V. (2020). Models of experimental pseudomonas keratitis: microbiological and clinical aspects. Reports of Vinnytsia National Medical University, 24 (1), $129-133$. doi: http://doi.org/10.31393/reports-vnmedical-2020-24(1)-25

22. Vovk, I. M., Kryvetska, N. V., Burkot, V. M., Dudar, A. O., Kulik, A. V. (2020). Microbiological grounds for antimicrobial treatment of experimental pseudomonal keratitis. Reports of Vinnytsia National Medical University, 24 (1), 114-117. doi: http:// doi.org/10.31393/reports-vnmedical-2020-24(1)-21

23. Lin, A., Rhee, M. K., Akpek, E. K., Amescua, G., Farid, M., Garcia-Ferrer, F. J. et. al. (2019). Bacterial Keratitis Preferred Practice Pattern®. Ophthalmology, 126 (1), 1-55. doi: http://doi.org/10.1016/j.ophtha.2018.10.018

24. Rasamiravaka, T., Labtani, Q., Duez, P., El Jaziri, M. (2015). The Formation of Biofilms by Pseudomonas aeruginosa: A Review of the Natural and Synthetic Compounds Interfering with Control Mechanisms. BioMed Research International, $2015,1-17$. doi: http://doi.org/10.1155/2015/759348

25. Nazarchuk, O., Chereshniuk, I., Nazarchuk, G., Palii, D. et. al. (2019). Current antiseptics: a study on their antimicrobial activity and toxic effects on the corneal epithelium. Oftalmologicheskii Zhurnal, 80 (3), 26-31. doi: http://doi.org/10.31288/oftalmolzh201932631

26. Bezwada, P., Clark, L. A., Schneider, S. (2007). Intrinsic cytotoxic effects of fluoroquinolones on human corneal keratocytes and endothelial cells. Current Medical Research and Opinion, 24 (2), 419-424. doi: http://doi.org/10.1185/030079908x261005

Received date 01.06.2020

Accepted date 24.06.2020

Published date 31.07.2020

Nataliia Malachkova, PhD, Associate Professor, Head of Department, Department of Ophtalmology, National Pirogov Memorial Medical University, Pirogova str., 56. Vinnitsya, Ukraine, 21018

E-mail: malachkovanataliia@gmail.com

Nelia Kryvetska, Postgraduate Student, Department of Ophtalmology, National Pirogov Memorial Medical University, Pirogova str., 56. Vinnitsya, Ukraine, 21018

E-mail: kryvetska.n@gmail.com

Volodymyr Kryvetskyi, PhD, Associate Professor, Department of Surgery No. 1, National Pirogov Memorial Medical University, Pirogova str., 56. Vinnitsya, Ukraine, 21018

E-mail: kryvetsky.v@gmail.com 